DOI: 10.22616/REEP.2021.14.041

\title{
Understanding the Concept of Sustainable Food Consumption - whether it will Reduce Meat Consumption
}

Krystyna Rejman ${ }^{1}$ Dr. hab.; (iD) Marzena Jeżewska-Zychowicz ${ }^{2}$ Dr. hab.; (1) Grzegorz Ganczewski ${ }^{3}$ MA Warsaw University of Life Sciences WULS-SGGW, Institute of Human Nutrition Sciences, Department of Food Market and Consumer Research, Poland ${ }^{1,2}$

Łukasiewicz Research Centre - Biopolymers and Chemical Fibres Institute Warsaw Branch, COBRO - Packaging Research and Development Centre, Poland ${ }^{3}$

krystyna_rejman@sggw.edu.pl ${ }^{1}$; marzena_jezewska_zychowicz@sggw.edu.pl ${ }^{2}$ grzegorz.ganczewski@ibwch.lukasiewicz.gov.pl ${ }^{3}$

\begin{abstract}
Despite the evidence-based health and environment benefits of sustainable diets and the urgent need to change consumption patterns in well-developed countries into plant-based diet, people are reluctant to limit meat consumption. The aim of the study was to examine the attachment to meat consumption in a group of Polish consumers and whether it depends on an understanding of the concept of sustainable food consumption (SFC). The study was carried out using the Computer Assisted Web Interview method on a sample of 199 consumers, who met two criteria of inclusion: age (20 - 65 years old) and not excluding meat from the diet. The questionnaire included a tool to measure the attachment to eating meat in 4 dimensions: hedonism, affinity, entitlement, and dependence. The analysis of the results was carried out in the Statistica software. Pearson Chi-squared test and Student's t-test were performed to investigate the significance of differences between the two variables ( $\mathrm{p} \leq 0.05)$. In the surveyed group only $35 \%$ of respondents interpreted the term of sustainable food consumption correctly and among them there were more people with higher education. Interviewees were rather strongly attached to eating meat and this was firstly due to the belief in human right to eat meat, secondly - taste preferences and hedonism, thirdly - dependence on eating meat. The ethical motives (affinity) were rated lowest, but significantly higher by respondents understanding the concept of sustainable diet. Their opinions on all aspects of attachment to eating meat were more pro-environmental than those of respondents who did not understand the idea (although the differences in the opinions were not statistically significant). Our results indicate the need to implement effective educational programs that will show all benefits of a sustainable diet to provide consumers with reliable knowledge and on this basis influence their attitudes and support them in making healthier and more sustainable choices in the food market.
\end{abstract}

Keywords: sustainable diet, food, consumption, meat, meat attachment.

\section{Introduction}

Growing production and demand for meat are determined by the economic development of the world (Milford et al., 2019; Salter, 2017; Naarod, Tiongco, Scott, 2011; Delagado, 2003), including emerging economies such as China, where the growth rate of meat demand is very high (Food Outlook..., 2020; Liu, Debiltz, 2007). According to FAO (Food and Agriculture Organisation of the United Nations), since the early 1960s, world meat production has increased nearly fivefold and reached 341 million tons in 2018 (Food Outlook..., 2020). The largest increase, almost 16 times over, occurred in the Asian region, where production was 9 million tons in 1961 and reached 144 million tons in 2018. The second region in terms of growth dynamics was South America, with a 7-fold increase, from 7 million tons to 46 million tons respectively in those years. In North America, production has increased almost 3 times, and the smallest, twofold increase was recorded in Europe, from 30 million tons to 64 million tons, which is due, among other factors, to the lowest population growth in this region of the world. The share of other regions in world meat production is currently only $10 \%$.

In the same period (1961-2017), global meat consumption almost doubled, from 23 to $43 \mathrm{~kg} /$ person/year. The highest growth rate was recorded for poultry meat, whose consumption increased 5.3 times, from less than 3 to $15 \mathrm{~kg} /$ person. Pig meat consumption was also characterized by an upward trend - the increase was twofold, from 8 to $16 \mathrm{~kg} /$ person. The consumption of other types of meat remained at the same level (with a minimal decrease), in the case of bovine meat it was $9 \mathrm{~kg} /$ person, in the case of mutton and goat meat - less than $2 \mathrm{~kg} /$ person (FAOSTAT, 2020). 
This data includes the enormity of processes that occur in the global food production value chain and the cost of this development and the growing consumption of meat has severe environmental and climate implications.

Food production is a major driver of greenhouse gas emissions, water and land use (Aleksandrowicz et al., 2016). The entire global food chain produces about 13.7 giga tonnes of $\mathrm{CO}_{2}$ equivalent (Poore, Nemecek, 2018). The livestock sector alone is responsible for 8.1 giga tonnes of $\mathrm{CO}_{2}$ equivalent. Methane released from intestinal fermentation in livestock organisms accounts for half of these emissions, and nitrous oxide and carbon dioxide have an almost equal share of 24 and $26 \%$ respectively (Global Livestock Environmental..., 2018). From an environmental point of view, it is also inefficient to grow cereals for animal feed (Scarborough et al., 2014). Agriculture uses about $70 \%$ of all fresh water resources (Springmann et al., 2018). Food production causes about $32 \%$ of global terrestrial acidification and $78 \%$ of water eutrophication. These emissions change natural ecosystems and reduce environmental biodiversity. All these harmful impacts lead to the crossing of several boundaries in the use of the planet's resources that define a safe space for humanity in the earth system (Campbell et al., 2017).

Stopping these unfavourable processes is currently the most important challenge for international institutions, governments, stakeholders in food systems and food consumers. The changes desired to food systems generate a demand for well-educated specialists, representing ecologically-minded personalities, capable of making appropriate and responsible decisions in competitive conditions of constantly changing environment (Iriste, Katane, 2020). Many countries have already revised dietary guidelines for their populations and these changes are moving towards a sustainable food consumption model (Rejman et al., 2019; Kramer et al., 2017). Sustainable diets have "low environmental impacts which contribute to food and nutrition security and to healthy life for present and future generations. Sustainable diets are protective and respectful of biodiversity and ecosystems, culturally acceptable, accessible, economically fair and affordable; nutritionally adequate, safe and healthy; while optimizing natural and human resources" (Burlingame, Dernini, 2010). This definition shows the multithreaded nature of the issue as it covers food security, health and well-being, local, seasonal and eco-friendly foods, cultural heritage and skills, equity, and directly related to the environment - biodiversity, ecosystem services and climate (Johnston, Fanzo, Cogill, 2014). The structure of a sustainable diet was developed as part of the international EAT-Lancet Commission initiative (Willett et al., 2019). A sustainable diet is based on plant products, as half the weight of the food consumed during the day should be made up of vegetables and fruits, one third - whole grains, starchy vegetables (roots and tubers) and plant sourced protein (pulses, nuts and seeds), while animal sourced protein - together with meat, fish and eggs less than $5 \%$. The recommendation to limit the consumption of all types of meat and meat products is included in the dietary guidelines of all medium and highly developed countries (Food-Based Dietary..., 2020; Fischer, Garnett, 2016).

With this in mind, the aim of the study was to examine, in detail, the attachment to meat consumption in the group of Polish consumers in the context of their knowledge and understanding of the concept of SFC and their behaviour, knowledge and opinions related to the implementation of this food consumption model.

\section{Methodology}

The survey data was collected using the Computer Assisted Web Interview method and the questionnaire was prepared in Google Form. Two criteria for participation in the study were defined: age of 20 - 65 years and not excluding meat from the diet. The survey was conducted from 12.XII.2019 to 12.I.2020. It was attended by 237 people, however, after verification of the obtained data, 199 questionnaires were accepted for analysis (22 people did not meet the inclusion criteria, 16 questionnaires were found to be missing answers). The sociodemographic characteristics of the study sample are presented in Table 1. The questionnaire included questions concerning knowledge and understanding of the concept of SFC as well as selected behaviours and opinions related to the concept of this consumption model. The Meat Attachment Questionnaire (MAQ) (Graça, Calheiros, Oliveira, 2015) was used to measure attachment to eating meat, containing 19 statements to evaluate adherence to eating meat in 4 categories: hedonism, affinity (compassion for animals), entitlement (human right to eat meat), and dependence (addiction to eating meat). Respondents were also asked about their attitude to the possibility of limiting consumption of meat and preserves. In the questions, a 5-point Likert-type scale was used. Statistical analysis of the 
results was carried out using the Statistica software version 13.3. Pearson Chi-square test and Student's t-test were performed to investigate the significance of differences between the two variables. The significance level of $\mathrm{p} \leq 0.05$ was adopted.

Table 1

Socio-demographic characteristics of the study sample

\begin{tabular}{|c|c|c|c|}
\hline \multirow[t]{2}{*}{ Characteristics } & \multirow{2}{*}{$\begin{array}{c}\text { Total sample } \\
{[\%(\mathrm{~N})]} \\
100.0(199)\end{array}$} & \multicolumn{2}{|c|}{ Understanding of the concept SFC } \\
\hline & & $\begin{array}{c}\text { correct }[\%(n)] \\
34.7 \%(69)\end{array}$ & $\begin{array}{c}\text { incorrect }[\%(\mathrm{n})] \\
65.3 \%(130)\end{array}$ \\
\hline \multicolumn{4}{|l|}{ Gender $(p>0.05)$} \\
\hline $\begin{array}{l}\text { Female } \\
\text { Male }\end{array}$ & $\begin{array}{c}81.4(162) \\
18.6(37)\end{array}$ & $\begin{array}{l}35.2(57) \\
32.4(12)\end{array}$ & $\begin{array}{c}64.8(105) \\
67.6(25)\end{array}$ \\
\hline \multicolumn{4}{|l|}{ Age (years $)(p>0.05)$} \\
\hline $\begin{array}{l}20-35 \\
36-45 \\
46-55 \\
56-65\end{array}$ & $\begin{array}{c}79.4(158) \\
12.6(25) \\
5.0(10) \\
3.0(6)\end{array}$ & $\begin{array}{c}35.4(56) \\
32.0(8) \\
30.0(3) \\
40.0(2)\end{array}$ & $\begin{array}{c}64.6(102) \\
68.0(17) \\
70.0(7) \\
60.0(4)\end{array}$ \\
\hline \multicolumn{4}{|c|}{ Size of place of residence (no. of inhabitants) $(p<0.05)$} \\
\hline $\begin{array}{l}\text { Rural area } \\
\text { Cities up to } 200000 \\
\text { City }>200000\end{array}$ & $\begin{array}{l}24.6(49) \\
31.7(63) \\
43.7(87)\end{array}$ & $\begin{array}{c}18.5(9) \\
33.3(21) \\
55.2(39)\end{array}$ & $\begin{array}{l}81.6(40) \\
66.7(42) \\
55.2(48)\end{array}$ \\
\hline \multicolumn{4}{|l|}{ Education $(p>0.05)$} \\
\hline $\begin{array}{l}\text { High school or lower } \\
\text { Higher education/university }\end{array}$ & $\begin{array}{c}50.3(100) \\
49.7(99)\end{array}$ & $\begin{array}{l}33.0(33) \\
36.4(36)\end{array}$ & $\begin{array}{l}67.0(67) \\
63.6(63)\end{array}$ \\
\hline
\end{tabular}

\section{Results and Discussion}

More than half of the respondents $(52.8 \%)$ declared that the concept of SFC has already been met. In contrast, K. Rejman, B. Kowrygo, W. Laskowski (2015) and A. Szczebyło, K. Rejman, E. Halicka and W. Laskowski (Szczebyło et al., 2020) received such declarations from a smaller percentage of respondents $(33-39 \%)$. Statistical analysis $(\mathrm{p}<0.05)$ showed differences in the declarations in accordance with respondent education level. Respondents with higher education displayed significantly more affirmative declarations. Nearly $2 / 3$ of respondents with higher education $(61.6 \%)$ and $43.6 \%$ with secondary education declared their familiarity with the term of SFC. However, the correct interpretation of the concept 'everyday diet is carried out so as to minimize the influence on the natural environment' was known to far fewer respondents $(34.7 \%)$ (Figure 1).

In the food consumed there is the same share of plant and animal products

Everyday diet is carried out so as to minimize the influence on the natural environment

The energy value of food consumed equals the energy expended by the body

Food products are selected so as to provide all the necessary nutrients

The cost of nutrition is adapted to the financial capabilities of the household.

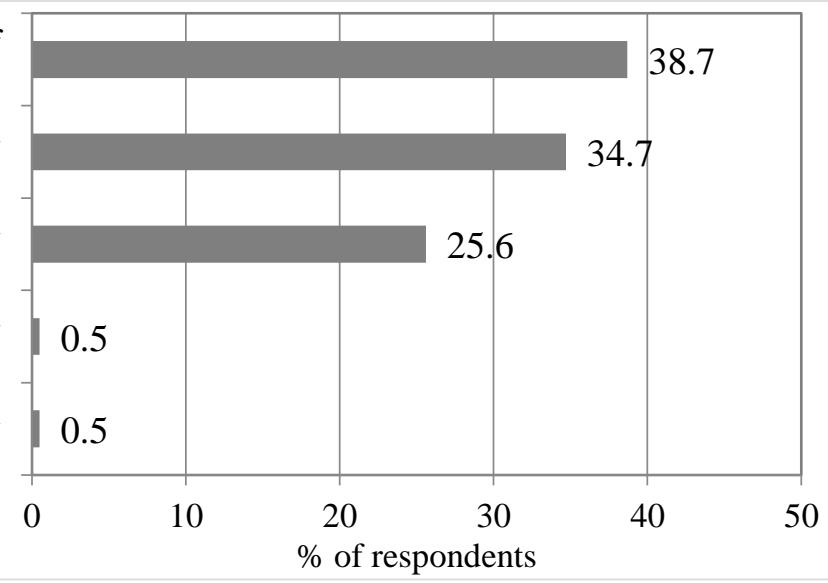

Figure 1. Understanding the concept of sustainable food consumption, $\%$ of respondents

In the correct answer, the definition has been deliberately simplified and narrowed down to the environmental dimension, since its fulfilment is crucial to achieve economic and social benefits. The inclusion of all complex aspects of sustainability into the proposed options could have been too suggestive 
and draw the respondents' attention straight to this answer. Nearly $40 \%$ of people incorrectly indicated that the term SFC refers to food with the same proportion of plant and animal products. Every fourth respondent confused this concept with the concept of a balanced diet. The low awareness of SFC and the impact of dietary choices on health and the environment among Polish consumers were also confirmed in other countries (Grunert, 2017). Behaviours and opinions in accordance with SFC rules are presented in Table 2.

Table 2

Behaviour, knowledge and opinions related to sustainable food consumption rules

\begin{tabular}{|c|c|c|c|c|c|c|}
\hline \multirow[t]{3}{*}{ Statements } & \multicolumn{3}{|c|}{$\begin{array}{l}\text { Score on 5-point } \\
\text { Likert-type scale }^{1}\end{array}$} & \multirow{3}{*}{$\begin{array}{c}\text { Opinion } \\
\text { of total } \\
\text { sample } \\
\left(\text { Mean }^{\prime} \mathbf{S D}^{2}\right)\end{array}$} & \multirow{2}{*}{\multicolumn{2}{|c|}{$\begin{array}{c}\text { Understanding of } \\
\text { the SFC concept } \\
(\text { Mean } \pm \text { SD })\end{array}$}} \\
\hline & $5+4$ & 3 & $2+1$ & & & \\
\hline & \multicolumn{3}{|c|}{$\%$ of respondents } & & correct & incorrect \\
\hline $\begin{array}{l}\text { I prefer to buy domestic fruit and vegetables } \\
\text { because they were produced close to me }\end{array}$ & 66.4 & 28.1 & 5.5 & $\begin{array}{l}3.92 \\
\pm 0.91 \\
\end{array}$ & $\begin{array}{l}4.01 \\
\pm 0.91 \\
\end{array}$ & $\begin{array}{l}3.87 \\
\pm 0.97 \\
\end{array}$ \\
\hline $\begin{array}{l}\text { For the same money, I prefer to buy less good } \\
\text { quality food than more of average quality }\end{array}$ & 55.7 & 30.2 & 14.1 & $\begin{array}{l}3.65 \\
\pm 1.08\end{array}$ & $\begin{array}{l}3.65 \\
\pm 1.15\end{array}$ & $\begin{array}{l}3.65 \\
\pm 1.04\end{array}$ \\
\hline $\begin{array}{l}\text { I manage water and energy sparingly when } \\
\text { preparing food }\end{array}$ & 59.8 & 20.1 & 20.1 & $\begin{array}{l}3.57 \\
\pm 1.03\end{array}$ & $\begin{array}{l}3.81 a \\
\pm 1.02\end{array}$ & $\begin{array}{l}3.44 a \\
\pm 1.01\end{array}$ \\
\hline $\begin{array}{l}\text { I usually drink tap water and drinks made from } \\
\text { tap water }\end{array}$ & 49.2 & 15.1 & 35.7 & $\begin{array}{l}3.20 \\
\pm 1.42\end{array}$ & $\begin{array}{l}3.33 \\
\pm 1.35\end{array}$ & $\begin{array}{l}3.13 \\
\pm 1.45\end{array}$ \\
\hline $\begin{array}{l}\text { Meat or meat preserves must be present in the } \\
\text { daily diet }\end{array}$ & 49.3 & 17.6 & 33.1 & $\begin{array}{l}3.20 \\
\pm 1.31 \\
\end{array}$ & $\begin{array}{l}2.83 b \\
\pm 1.37\end{array}$ & $\begin{array}{l}3.39 b \\
\pm 1.24\end{array}$ \\
\hline $\begin{array}{l}\text { I am willing to buy imported fruit and } \\
\text { vegetables }\end{array}$ & 33.6 & 42.2 & 24.2 & $\begin{array}{l}3.14 \\
\pm 0.93\end{array}$ & $\begin{array}{l}3.20 \\
\pm 0.90\end{array}$ & $\begin{array}{l}3.10 \\
\pm 0.95\end{array}$ \\
\hline $\begin{array}{l}\text { The consequence of vegetarian diet is iron } \\
\text { deficiency/anaemia }\end{array}$ & 35.2 & 21.6 & 43.2 & $\begin{array}{l}2.90 \\
\pm 1.34\end{array}$ & $\begin{array}{l}3.10 \\
\pm 1.33\end{array}$ & $\begin{array}{l}2.79 \\
\pm 1.34\end{array}$ \\
\hline $\begin{array}{l}\text { In my household you have to throw away food } \\
\text { once-several times a week }\end{array}$ & 42.2 & 13.1 & 44.7 & $\begin{array}{l}2.89 \\
\pm 1.27\end{array}$ & $\begin{array}{l}2.71 \\
\pm 1.24\end{array}$ & $\begin{array}{l}2.99 \\
\pm 1.28\end{array}$ \\
\hline I usually buy more food than I need & 35.1 & 16.1 & 48.8 & $\begin{array}{l}2.84 \\
\pm 1.15\end{array}$ & $\begin{array}{l}2.62 \\
\pm 1.13\end{array}$ & $\begin{array}{l}2.95 \\
\pm 1.15\end{array}$ \\
\hline $\begin{array}{l}\text { I buy products with certificate labels, e.g., fair } \\
\text { Trade, UTZ, PDO }\end{array}$ & 18.6 & 28.6 & 52.8 & $\begin{array}{l}2.48 \\
\pm 1.09\end{array}$ & $\begin{array}{l}2.64 \\
\pm 1.17\end{array}$ & $\begin{array}{l}2.40 \\
\pm 1.04 \\
\end{array}$ \\
\hline $\begin{array}{l}\text { I do not actually buy water or other beverages } \\
\text { in plastic bottles }\end{array}$ & 26.2 & 8.5 & 65.3 & $\begin{array}{l}2.42 \\
\pm 1.37\end{array}$ & $\begin{array}{l}2.62 \\
\pm 1.39\end{array}$ & $\begin{array}{l}2.32 \\
\pm 1.35 \\
\end{array}$ \\
\hline I buy certified organic products & 14.6 & 27.6 & 57.8 & $\begin{array}{l}2.34 \\
\pm 1.10\end{array}$ & $\begin{array}{l}2.42 \\
\pm 1.30\end{array}$ & $\begin{array}{l}2.30 \\
\pm 0.99\end{array}$ \\
\hline Food in Poland is cheap & 15.1 & 28.1 & 56.8 & $\begin{array}{l}2.31 \\
\pm 1.13\end{array}$ & $\begin{array}{l}2.32 \\
\pm 1.11\end{array}$ & $\begin{array}{l}2.30 \\
\pm 1.15\end{array}$ \\
\hline
\end{tabular}

1 1-definietly not; 2-rather not; 3-neutral; 4-rather yes, 5-definitely yes; ${ }^{2} \mathrm{SD}$ - standard deviation;

$\mathrm{a}, \mathrm{b}$ - values marked with the same letters differ significantly $(\mathrm{p}<0.05)$

Respondents most agreed that they prefer to buy domestic vegetables and fruits because of their proximity to the place of production/local production (mean 3.92, only $5.5 \%$ disagreed or rather disagreed). A. Dąbrowska (2015) and J. Kaczorowska and B. Kowrygo (2016) also found such an attitude in their studies. In our survey, the mean scores above 3.50 were also given to two more statements: 'For the same money, I prefer to buy less good quality food than more of average quality' and 'I manage water and energy sparingly when preparing food'. Respondents with a correct understanding of the SFC concept scored higher economical use of water and energy compared to respondents with no understanding of this concept. On the basis of the national survey examining pro-ecological behaviour of Poles (representative adult sample) K. Wądołowska (2011) stated that the issue of rational water and energy management is essential for 90 and $83 \%$ of respondents respectively. The pro-environmental habit of drinking tap water and tap water drinks was ranked fourth in terms of average rating (3.20). At the same time only $1 / 4$ of the respondents confirmed this behaviour by declaring that they do not actually buy water and beverages in plastic bottles (mean 2.42). 
Z. Hu, L.W. Morton, L.R. Mahler (2011) noted that putting tap water above bottled water depends on the perception of quality and safety of tap water. Almost half of the respondents admitted that meat and preserves must be present in their daily diet, and one-third had the opposite opinion. These opinions differed significantly from the understanding of the SFC concept. The mean score of respondents correctly understanding the concept of SFC was lower (as expected) (mean 2.83) compared to respondents with a wrong understanding of the concept (mean 3.39).

Summarizing the results from Table 2, it can be stated that the interviewees respect most of the principles of SFC. Exceptionally, they actually ignore the validity of buying high quality, certified food products, which is contrary to the SFC concept. The quality of food products is a complex process, as consumers judge different quality attributes depending on their individual preferences and other food choice determinants (Grunert, 2005). However, certification labels require some degree of nutritional literacy and are difficult to interpret for many people (HLPE, 2017).

Restricting meat consumption is one of the more urgent SFC rules that must be implemented. The rationale is based on environmental considerations (outlined in the 'Introduction' chapter) and, equally important, on health considerations, dictated by the need to halt the spread of diet-related diseases, including cancer and obesity (Meat, Fish and..., 2018; Bouvard et al., 2015). The third group of arguments are ethical considerations, understood broadly, not only as respect for animals and life.

Interestingly, the results of our research showed that the respondents perceived eating meat in the category of human right to eat meat and hedonism. The highest mean score was obtained by three statements from both categories (Table 3). The hierarchy of factors of attachment to meat is opened by the statement that 'people have the right to eat meat given the position of the human being in the food chain' - $68 \%$ of respondents had such a belief and the mean score was 3.79. More than half of the respondents displayed the opinion that eating meat 'is an unquestionable right of every person' and that it is 'a natural and undisputable practice' in human nutrition. The views on the latter issue differed significantly in the understanding of the SFC concept - unconscious respondents rated this statement higher (mean 3.55 vs 3.10). Hedonic attitude to eating meat by admitting that one is a meat gourmet declared almost $60 \%$ of respondents ('I love meals with meat', 'A good steak is without comparison'). The study group included $35-45 \%$ of respondents who were addicted to eating meat. The limit percentages were those who agreed that 'if they could not eat meat, they would feel bad' and that 'meat is irreplaceable in their diet'. These results reflect the findings of M. Jezewska-Zychowicz (2018), who studied food culture among Polish consumers. It was found that changes in food culture are quite slow, both in relation to methods of food preparation and type of food consumed and traditional food patterns are preferred. All statements (5) concerning respect for animals/empathy were rated lowest by the respondents. They were disagreed with by $63 \%$ of respondents for the statement 'By eating meat I'm reminded of the death and suffering of animals' up to $85 \%$ for 'Meat sickens me'; and this statement received the lowest mean score of 1.61. In addition, the opinions of respondents on each of the statements in the affinity category were statistically different according to understanding of the concept of SFC. As expected, respondents who defined the SFC concept correctly were characterized by higher mean scores compared to respondents who did not understand it correctly.

In the study group there were three attitudes towards the possibility of reducing meat consumption. In the first group, $43.7 \%$ of the respondents were people with an anti-environmental attitude. These respondents did not intend to reduce meat consumption or have never considered such a change. Exactly the same percentage declared pro-environmental attitudes, declaring that they already care about eating smaller amounts of meat or stating that eating small amounts of meat is their habitual behaviour. A small percentage, about $13 \%$, declared that they were considering reducing meat consumption, but this is not yet supported by any action in this direction. 
Table 3

Respondents' opinions on issues concerning attachment to meat consumption

\begin{tabular}{|c|c|c|c|c|c|c|c|}
\hline \multirow{3}{*}{\multicolumn{2}{|c|}{ Statements }} & \multicolumn{3}{|c|}{$\begin{array}{l}\text { Score on 5-point } \\
\text { Likert-type scale }^{1}\end{array}$} & \multirow{3}{*}{ 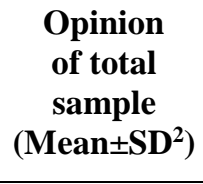 } & \multirow{2}{*}{\multicolumn{2}{|c|}{$\begin{array}{l}\text { Understanding of } \\
\text { the } \mathrm{SFC} \text { concept } \\
\left(\mathrm{Mean} \pm \mathrm{SD}^{2}\right)\end{array}$}} \\
\hline & & $5+4$ & 3 & $2+1$ & & & \\
\hline & & \multicolumn{3}{|c|}{ \% of respondents } & & correct & incorrect \\
\hline $\mathrm{E}^{3}$ & $\begin{array}{l}\text { According to our position in the food } \\
\text { chain, we have the right to eat meat }\end{array}$ & 67.9 & 18.6 & 13.5 & $\begin{array}{c}3.79 \\
\pm 1.16\end{array}$ & $\begin{array}{c}3.72 \\
\pm 1.17\end{array}$ & $\begin{array}{c}3.83 \\
\pm 1.15\end{array}$ \\
\hline $\mathrm{H}$ & I love meals with meat & 58.3 & 28.1 & 13.6 & $\begin{array}{c}3.66 \\
\pm 1.13\end{array}$ & $\begin{array}{c}3.45 \\
\pm 1.21\end{array}$ & $\begin{array}{c}3.77 \\
\pm 1.08\end{array}$ \\
\hline $\mathrm{H}$ & A good steak is without comparison & 57.3 & 26.6 & 16.1 & $\begin{array}{c}3.65 \\
\pm 1.23 \\
\end{array}$ & $\begin{array}{c}3.54 \\
\pm 1.25\end{array}$ & $\begin{array}{c}3.71 \\
\pm 1.21 \\
\end{array}$ \\
\hline $\mathrm{E}$ & $\begin{array}{l}\text { To eat meat is an unquestionable } \\
\text { right of every person }\end{array}$ & 51.7 & 25.6 & 22.6 & $\begin{array}{c}3.45 \\
\pm 1.35\end{array}$ & $\begin{array}{c}3.30 \\
\pm 1.41\end{array}$ & $\begin{array}{c}3.53 \\
\pm 1.31\end{array}$ \\
\hline $\mathrm{E}$ & $\begin{array}{l}\text { Eating meat is a natural and } \\
\text { undisputable practice }\end{array}$ & 52.3 & 23.1 & 24.7 & $\begin{array}{c}3.40 \\
\pm 1.26 \\
\end{array}$ & $\begin{array}{l}3.10 \mathrm{e} \\
\pm 1.34 \\
\end{array}$ & $\begin{array}{l}3.55 \mathrm{e} \\
\pm 1.19 \\
\end{array}$ \\
\hline $\mathrm{H}$ & $\begin{array}{l}\text { To eat meat is one of the good } \\
\text { pleasures in life }\end{array}$ & 44.2 & 29.1 & 26.7 & $\begin{array}{c}3.29 \\
\pm 1.25 \\
\end{array}$ & $\begin{array}{c}3.13 \\
\pm 1.24 \\
\end{array}$ & $\begin{array}{c}3.37 \\
\pm 1.26 \\
\end{array}$ \\
\hline $\mathrm{D}$ & Meat is irreplaceable in my diet & 45.2 & 17.6 & 37.2 & $\begin{array}{c}3.19 \\
\pm 1.33\end{array}$ & $\begin{array}{c}3.04 \\
\pm 1.37\end{array}$ & $\begin{array}{c}3.26 \\
\pm 1.31\end{array}$ \\
\hline E & $\begin{array}{l}\text { Meat consumption is crucial to my } \\
\text { balance }\end{array}$ & 43.2 & 22.6 & 34.2 & $\begin{array}{c}3.11 \\
\pm 1.33\end{array}$ & $\begin{array}{c}2.90 \\
\pm 1.42\end{array}$ & $\begin{array}{c}3.22 \\
\pm 1.28\end{array}$ \\
\hline $\mathrm{D}$ & $\begin{array}{l}\text { I don't picture myself without eating } \\
\text { meat regularly }\end{array}$ & 40.7 & 23.1 & 36.2 & $\begin{array}{c}3.07 \\
\pm 1.40 \\
\end{array}$ & $\begin{array}{c}2.88 \\
\pm 1.49 \\
\end{array}$ & $\begin{array}{c}3.16 \\
\pm 1.34 \\
\end{array}$ \\
\hline $\mathrm{H}$ & I am a big fan of meat & 36.7 & 29.1 & 34.2 & $\begin{array}{c}3.01 \\
\pm 1.29 \\
\end{array}$ & $\begin{array}{c}2.81 \\
\pm 1.35 \\
\end{array}$ & $\begin{array}{c}3.11 \\
\pm 1.26 \\
\end{array}$ \\
\hline $\mathrm{D}$ & $\begin{array}{l}\text { If I was forced to stop eating meat I } \\
\text { would feel sad }\end{array}$ & 39.2 & 15.1 & 45.7 & $\begin{array}{c}2.94 \\
\pm 1.46\end{array}$ & $\begin{array}{c}2.80 \\
\pm 1.47\end{array}$ & $\begin{array}{c}3.02 \\
\pm 1.45\end{array}$ \\
\hline $\mathrm{D}$ & $\begin{array}{l}\text { If I could not eat meat I would feel } \\
\text { weak }\end{array}$ & 35.2 & 15.6 & 49.2 & $\begin{array}{c}2.78 \\
\pm 1.42 \\
\end{array}$ & $\begin{array}{c}2.55 \\
\pm 1.36 \\
\end{array}$ & $\begin{array}{c}2.91 \\
\pm 1.45 \\
\end{array}$ \\
\hline $\mathrm{H}$ & A full meal is a meal with meat & 32.2 & 20.6 & 47.2 & $\begin{array}{r}2.75 \\
\pm 1.34 \\
\end{array}$ & $\begin{array}{c}2.61 \\
\pm 1.31 \\
\end{array}$ & $\begin{array}{c}2.82 \\
\pm 1.36 \\
\end{array}$ \\
\hline E & $\begin{array}{l}\text { Meat consumption is a natural act of } \\
\text { one's affirmation as a human being }\end{array}$ & 18.6 & 31.2 & 50.2 & $\begin{array}{c}2.54 \\
\pm 1.20 \\
\end{array}$ & $\begin{array}{c}2.36 \\
\pm 1.16 \\
\end{array}$ & $\begin{array}{c}2.63 \\
\pm 1.21 \\
\end{array}$ \\
\hline A & $\begin{array}{l}\text { By eating meat I am reminded of the } \\
\text { death and suffering of animals }\end{array}$ & 19.1 & 18.1 & 62.8 & $\begin{array}{c}2.36 \\
\pm 1.24\end{array}$ & $\begin{array}{l}2.69 \mathrm{~d} \\
\pm 1.24\end{array}$ & $\begin{array}{l}2.20 d \\
\pm 1.21\end{array}$ \\
\hline A & $\begin{array}{l}\text { To eat meat is disrespectful towards } \\
\text { life and the environment. }\end{array}$ & 10.0 & 17.1 & 72.9 & $\begin{array}{r}1.93 \\
\pm 1.05 \\
\end{array}$ & $\begin{array}{l}2.17 \mathrm{~b} \\
\pm 1.15 \\
\end{array}$ & $\begin{array}{l}1.80 \mathrm{~b} \\
\pm 0.98 \\
\end{array}$ \\
\hline A & $\begin{array}{l}\text { I feel bad when I think of eating } \\
\text { meat. }\end{array}$ & 6.5 & 12.1 & 81.4 & $\begin{array}{c}1.82 \\
\pm 0.98 \\
\end{array}$ & $\begin{array}{l}2.13 a \\
\pm 1.19\end{array}$ & $\begin{array}{l}1.65 a \\
\pm 0.81\end{array}$ \\
\hline A & Meat reminds me of diseases & 5.6 & 13.6 & 80.8 & $\begin{array}{c}1.77 \\
\pm 0.93\end{array}$ & $\begin{array}{l}2.03 \mathrm{c} \\
\pm 1.12\end{array}$ & $\begin{array}{l}1.64 \mathrm{c} \\
\pm 0.79\end{array}$ \\
\hline A & Meat sickens me & 4.5 & 10.6 & 84.9 & $\begin{array}{c}1.61 \\
\pm 0.94\end{array}$ & $\begin{array}{r}1.81 f \\
\pm 1.23\end{array}$ & $\begin{array}{r}1.50 f \\
\pm 0.80\end{array}$ \\
\hline
\end{tabular}

${ }^{1} 1$-strongly disagree; 2 -rather disagree; 3 -neither yes nor no; 4-rather agree, 5-strongly agree; ${ }^{2} \mathrm{SD}$ - standard deviation; ${ }^{3}$ type of statement: H-hedonism, A-affinity, E-entitlement, D-dependence; a - f - values marked with the same letters differ significantly $(\mathrm{p}<0.05)$

\section{Conclusions}

This study investigated the attachment to eating meat in a group of Polish consumers and examined if it is determined by understanding of the sustainable food consumption concept. It also surveyed certain behaviours, opinions and knowledge related to the implementation of this food consumption model in 
everyday nutrition. Only one out of three respondents interpreted the concept of SFC correctly, which signifies some progress compared to previous studies. The study group was rather strongly attached to eating meat (MAQ assessment) and this was due to the belief in the superiority of the human species in the food chain and the entitlement to eating meat, followed by hedonism and dependence of eating meat. The ethical motives (affinity) were rated lowest, but significantly higher by respondents understanding the concept of SFC correctly. Their opinions of other aspects of attachment to eating meat were more pro-environmental than those of respondents who did not understand the concept, but the differences were not statistically significant.

Based on an assessment of other SFC-specific consumer behaviours, it was found that respondents exhibited smart consumer behaviours that bring them economic benefits, including not buying certified products. In this case, half of the respondents confirmed their attachment to eating meat.

These can suggest that shifting to a more sustainable diet, with limited meat and preserves, will not be straightforward. It requires intensive promoting plant sources of protein and broad educational activities aimed to make food choices more determined by the factors that create responsible and sustainable eating habits.

\section{Bibliography}

1. Aleksandrowicz L., Green R., Joy E.J.M., Smith P. Haines A. (2016). The Impacts of Dietary Change on Greenhouse Gas Emissions, Land Use, Water Use, and Health: A systematic review. PLoS One, 11(11), No e0165797. doi: 10.1371/journal.pone.0165797

2. Bouvard V., Loomis D., Guyton K.Z., Grosse Y., El Ghissassi F., Benbrahim-Tallaa L., Guha N., Mattock H., Straif K. (2015). Carcinogenicity of Consumption of Red and Processed Meat. The Lancet Oncology, 16(16), 1599-1600. doi: 10.1016/S1470-2045(15)00444-1

3. Burlingame B., Dernini S. (Eds). (2010). Sustainable Diets and Biodiversity. Directions and Solutions for Policy, Research and Action. Rome: FAO. Retrieved from http://www.fao.org/3/i3004e/i3004e.pdf

4. Campbell B.M., Beare D.J., Bennett E.M., Hall-Spencer J.M., Ingram J.S.I., Jaramillo F., Ortiz R., Ramankutty N., Sayer A.J., Shindell D. (2017). Agriculture Production as a Major Driver of the Earth System Exceeding Planetary Boundaries. Ecology and Society, 22(4), No 8. doi: 10.5751/ES-09595-220408

5. Dąbrowska A. (2015). Postawy polskich konsumentów - od konsumpcjonizmu do zrównoważonej konsumpcji [Polish Consumers' Attitudes - from Consumerism to Sustainable Consumption].

Handel Wewnętrzny, 355(2), 88-100. Retrieved from http://cejsh.icm.edu.pl/cejsh/element/bwmeta1 .element.desklight-17c94154-c8e3-4ced-89a614e96ef1c4c4 (in Polish, abstract in English)

6. Delagado L.C. (2003). Rising Consumption of Meat and Milk in Developing Countries has Created a New Food Revolution. The Journal of Nutrition, 133(11), 3907-3910. doi: 10.1093/jn/133.11.3907S

7. FAOSTAT. (2020). Food Balances (old methodology and population). Retrieved from http://www.fao.org/faostat/en/\#data/FBSH

8. FAOSTAT. (2020). New Food Balances. Retrieved from http://www.fao.org/faostat/en/\#data/FBS/report

9. Fischer C.G., Garnett T. (2016). Plates, Pyramids and Planets. Developments in National Healthy and Sustainable Dietary Guidelines: A state of play assessment. Rome: FAO \& The Food Climate Research Network at The University of Oxford. Retrieved from http://www.fao.org/3/a-i5640e.pdf

10. Food-Based Dietary Guidelines. (2020). FAO. Retrieved from http://www.fao.org/nutrition/education/food-dietary-guidelines

11. Food Outlook - Biannual Report on Global Food Markets: June 2020, Food Outlook, 1. (2020). Rome: FAO. doi: 10.4060/ca9509en

12. Global Livestock Environmental Assessment Model. (2018). Food and Agriculture Organization of the United Nations of the United Nations. ( $5^{\text {th }}$ ed.). Retrieved from http://www.fao.org/fileadmin/user_upload/gleam/docs/GLEAM_2.0_Model_description.pdf

13. Graça J., Calheiros M.M., Oliveira A. (2015). Attached to Meat? (Un)Willingness and Intentions to Adopt a More Plant-Based Diet. Appetite, 95, 113-125. doi: 10.1016/j.appet.2015.06.024 
14. Grunert K.G. (2005). Food Quality and Safety: Consumer Perception and Demand. European Review of Agricultural Economics, 32(3); 369-391. doi: 10.1093/eurrag/jbi011

15. Grunert K.G. (2017). Food and Nutrition Security: A Consumer Perspective. In H. Biesalski, A. Drewnowski, J. Dwyer, J. Strain, P. Weber, M. Eggersdorfer (Eds.), Sustainable Nutrition in a Changing World. Cham: Springer, 279-282. doi: 10.1007/978-3-319-55942-1_20

16. HLPE. (2017). Nutrition and Food Systems. A Report by the High Level Panel of Experts on Food Security and Nutrition of the Committee on World Food Security. Rome: FAO. Retrieved from http://www.fao.org/3/a-i7846e.pdf

17. Hu Z., Morton L.W., Mahler L.R. (2011). Bottled Water: United States Consumer and Their Perceptions of Water Quality. International Journal of Environmental Research and Public Health, 8(2), 565-578. doi: 10.3390/ijerph8020565

18. Iriste S., Katane I. (2020). Entrepreneurial Competence Self-Evaluation of Prospective Engineers in Food Science within the Context of Competitiveness. In V. Dislere (Ed.), The Proceedings of the International Scientific Conference Rural Environment. Education. Personality (REEP), 13. Jelgava: Latvia University of Life Sciences and Technologies, 62-69. doi: 10.22616/REEP.2020.007

19. Jezewska-Zychowicz M. (2018). Cooking Methods, Social Relations and Situations Related to Food as a Part of Nutrition Education within Family. In V. Dislere (Ed.), Proceedings of the International Scientific Conference Rural Environment. Education. Personality (REEP), 11. Jelgava: Latvia University of Life Sciences and Technologies, 261-268. doi: 10.22616/REEP.2018.032

20. Johnston J.L., Fanzo J.C., Cogill B. (2014). Understanding Sustainable Diets: A Descriptive Analysis of the Determinants and Processes That Influence Diets and Their Impact on Health, Food Security, and Environmental Sustainability. Advances in Nutrition, 5(4), 418-429. doi: 10.3945/an.113.005553

21. Kaczorowska J., Kowrygo B. (2016). Konsumencka gotowość do realizacji zrównoważonego wzorca spożycia żywności [Consumer readiness to implement a balanced pattern of food consumption]. Zeszyty Naukowe Szkoły Głównej Gospodarstwa Wiejskiego Ekonomika i Organizacja Gospodarki Żywnościowej, 114, 33-44. Retrieved from http://sj.wne.sggw.pl/pdf/EIOGZ_2016_n114_s33.pdf

22. Kramer G., Durlinger B., Kuling L., Zeist W.J., Blonk H., Broekema R., Halevy S. (2017). Eating for 2 Degrees. New and Updated Livewell Plates. London: World Wide Fund for Nature. Retrieved from https://www.wwf.org.uk/sites/default/files/2017-06/Eating\%20for\%202\%20degrees_Full_Report.pdf

23. Liu H., Debiltz C. (2007). Determinants of Meat Consumption in China. Working Paper 40. Orange NSW: Asian Agribusiness Research Centre \& Charles Sturt University.

24. Meat, Fish and Dairy Product and the Risk of Cancer. (2018). World Cancer Research Fund and American Institute for Cancer Research. Retrieved from https://www.wcrf.org/sites/default/files/MeatFish-and-Dairy-products.pdf

25. Milford A.B., Le Mouël C., Bodirsky B.L., Rolinski S. (2019). Drivers of Meat Consumption. Appetite, 141, 104313. doi: 10.1016/j.appet.2019.06.005

26. Naarod C., Tiongco M., Scott R. (2011). Current and Predicted Trends in the Production, Consumption and Trade of Live Animals and Their Products. Revue Scientifique et Technique, 30, 31-49. doi: 10.20506/rst.30.1.2014

27. Poore J., Nemecek T. (2018). Reducing Food's Environmental Impacts Through Producers and Consumer. Science, 360(6392), 987-992. doi: 10.1126/science.aaq0216

28. Rejman K., Kaczorowska J., Halicka E., Laskowski W. (2019). Do Europeans Consider Sustainability When Making Food Choices? A Survey of Polish City Dwellers. Public Health Nutrition, 22(7), 1330-1339. doi: 10.1017/S1368980019000326

29. Rejman K., Kowrygo B., Laskowski W. (2015). Ocena struktury spożycia w Polsce w aspekcie wymogów zrównoważonej konsumpcji [Assessment of the consumption structure in Poland in the aspect of sustainable consumption requirements]. Journal of Agribusiness and Rural Development, 37(3), 503-512. doi: 10.17306/JARD.2015.54 (in Polish, abstract in English)

30. Salter M.A. (2017). Improving the Sustainability of Global Meat and Milk Production. The Proceedings of the Nutrition Society, 76(1), 22-27. doi: 10.1017/S0029665116000276

31. Scarborough P., Appleby P.N., Mizdrak A., Briggs A.D.M., Travis R.C., Bradbury K.E., Key T.J. (2014). Dietary Greenhouse Gas Emissions of Meat-Eaters, Fish-Eaters, Vegetarians and Vegans in the UK. Climatic Change, 125, 179-192. doi: 10.1007/s10584-014-1169-1 
32. Springmann M., Wiebe K., Mason-D'Croz D., Sulser T.B., Rayner M., Scarborough P. (2018). Health and Nutritional Aspects of Sustainable Diet Strategies and Their Association with Environmental Impacts: A global modelling analysis with country-level detail. Lancet Planet Health, 2(10), e451-e461. doi: 10.1016/S2542-5196(18)30206-7

33. Szczebyło A., Rejman K., Halicka E., Laskowski W. (2020). Towards More Sustainable Diets Attitudes, Opportunities and Barriers to Fostering Pulse Consumption in Polish Cities. Nutrients, 12(6), 1589. doi: 10.3390/nu12061589

34. Wądołowska K. (2011). Zachowania proekologiczne Polaków [Ecological behavior of Poles]. CBOS, BS/23/2011. Retrieved from https://www.cbos.pl/SPISKOM.POL/2011/K_023_11.PDF

35. Willett W., Rockström J., Loken B., Springmann M. (2019). Food in the Anthropocene: the EATLancet Commission on healthy diets from sustainable food systems. Lancet, 393(10170), 447-492. doi: 10.1016/S0140-6736(18)31788-4 